voluntary reporting, and no conclusions can be drawn about the comparative incidence of adverse effects to different drugs. Our data show that indapamide may cause skin reactions, and the Dutch experience suggests that cross sensitivity to other thiazides is probably rare. Rashes with indapamide were frequently reported, but whether these are relatively frequent can be confirmed or disproved only by further study.

1 Tweeddale MG. Diuretic drugs. In: Dukes MNG, ed. Meyler's side effects of drugs. 9th ed. Amsterdam: Excerpta Medica, 1980:337-67.

(Accepted 9 September 1987)

Netherlands Centre for Monitoring of Adverse Reactions to Drugs, PO Box 5406, 2280 HK Rijswijk, The Netherlands

B H Ch STRICKER, MB, PHD, medical officer

World Health Organisation Collaborating Centre for International Drug Monitoring, Uppsala, Sweden

C BIRIELL, MSC, pharmaceutical officer

Correspondence to: Dr Stricker.

\section{Measles in adults: a prospective study of 291 consecutive cases}

Since the introduction of measles vaccine in the mid-1960s the incidence of the disease has declined significantly. ${ }^{12}$ As a result unvaccinated children born in the early 1960s were not exposed to large scale epidemics and grew to after the fourth day of admission. None of the patients had overt jaundice. Serum creatine phosphokinase activities were abnormally high in $94(41 \%)$ of the patients; isoenzyme assays showed that the increase in activity was limited to the MM fraction-that is, it was of muscle origin. Complications of measles that developed during the study were keratitis (31 patients), sinusitis (11), otitis media (11), and pneumonia (6).

\section{Comment}

Several features seemed to characterise the measles syndrome in adults in the community. Firstly, liver function was impaired in $86 \%$ of our patients, and this should therefore be regarded as a characteristic symptom in adults rather than a complication. This is in contrast with the findings of Gavish et al, who concluded that the incidence of measles hepatitis is close to $4 \%$, assuming that milder forms of measles were not associated with hepatitis. ${ }^{4}$ Secondly, gastrointestinal symptoms - namely, vomiting, diarrhoea, and abdominal pain-occurred in one third of our patients. Thirdly, musculoskeletal symptoms-namely, myalgia, arthralgia, and back pain-were fairly common, and the incidence of raised serum creatine phosphokinase activity (a possible indication of viral myositis) was $41 \%$. Fourthly, Koplik's spots persisted for on average three to five days, although in $15 \%$ of the patients they were present on the seventh day of the disease, five days after the rash developed. Finally, photophobia was reported in only $1 \%$ of patients; the commonest eye complaint was pain that was not affected by light $(78 \%)$.

These features in adults differ from the symptoms of measles in childhood: symptomatic enteritis or enterocolitis is rare in otherwise healthy children ${ }^{\text {; }}$ musculoskeletal symptoms have not been reported; Koplik's spots have usually resolved by the end of the second day of the rash ${ }^{5}$; and photophobia is a classic symptom in children.

We are indebted to Mrs J Misch for her invaluable help in collecting and analysing the data and in preparing this manuscript.

Symptoms, physical findings, and results of blood tests in adults with measles

\begin{tabular}{|c|c|c|c|c|c|}
\hline Symptom & $\begin{array}{l}\text { No of patients } \\
(n=291)\end{array}$ & $\begin{array}{l}\text { Physical } \\
\text { findings }\end{array}$ & $\begin{array}{l}\text { No of patients } \\
\quad(n=291)\end{array}$ & $\begin{array}{c}\text { Blood } \\
\text { test }\end{array}$ & $\begin{array}{l}\text { No of patients } \\
\quad(n=230)\end{array}$ \\
\hline $\begin{array}{l}\text { Fever } \\
\text { Cough } \\
\text { Malaise } \\
\text { Sore throat } \\
\text { Coryza } \\
\text { Eye pain } \\
\text { Headache } \\
\text { Nausea } \\
\text { Myalgia } \\
\text { Vomiting } \\
\text { Abdominal pain } \\
\text { Diarrhoea } \\
\text { Ear pain } \\
\text { Hoarseness } \\
\text { Arthralgia } \\
\text { Pruritus } \\
\text { Back pain } \\
\text { Dysuria } \\
\text { Photophobia }\end{array}$ & $\begin{array}{r}291 \\
282 \\
264 \\
264 \\
243 \\
228 \\
219 \\
159 \\
102 \\
101 \\
97 \\
93 \\
72 \\
70 \\
69 \\
47 \\
32 \\
8 \\
3\end{array}$ & $\begin{array}{l}\text { Rash } \\
\text { Conjunctivitis } \\
\text { Pharyngitis } \\
\text { Lymphadenopathy } \\
\text { Koplik's spots } \\
\text { Aphthous stomatitis } \\
\text { Splenomegaly } \\
\text { Abdominal tenderness } \\
\text { Hepatomegaly }\end{array}$ & $\begin{array}{r}291 \\
279 \\
275 \\
246 \\
188 \\
34 \\
32 \\
15 \\
7\end{array}$ & 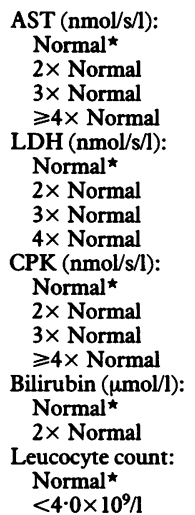 & $\begin{array}{r}75 \\
84 \\
30 \\
41 \\
\\
67 \\
147 \\
15 \\
1 \\
\\
136 \\
51 \\
18 \\
25 \\
\\
211 \\
19 \\
\\
157 \\
73\end{array}$ \\
\hline
\end{tabular}

AST $=$ Serum aspartate transaminase. $\mathrm{LDH}=$ Lactate dehydrogenase. $\mathrm{CPK}=$ Creatine phosphokinase.

${ }^{\star}$ Normal ranges: AST $\leqslant 330 \mathrm{nmol} / \mathrm{s} / 1 ; \mathrm{LDH} \leqslant 3670 \mathrm{nmol} / \mathrm{s} / 1 ;$ CPK $\leqslant 1170 \mathrm{nmol} / \mathrm{s} / 1 ;$ bilirubin $\leqslant 17 \mu \mathrm{mol} / 1 ;$ leucocyte count $4 \cdot 0-10 \cdot 8 \times 10^{9} / 1$.

adulthood without acquiring the disease. Reports of measles in young adults began to appear during the late $1970 \mathrm{~s},{ }^{3}$ but these were mainly of patients admitted to hospital and did not show the clinical picture of the disease in the community. After an outbreak of measles in Israel in 1982 the surgeon general issued an order whereby all soldiers with the disease, regardless of its severity, were admitted to hospital. This permitted a prospective study of consecutive adults with measles.

\section{Patients, methods, and results}

Measles was diagnosed clinically in 291 patients and confirmed in 100 of these by a fourfold rise in serum antibody titre to the virus on haemagglutination inhibition. In four cases only a twofold rise was found. Medical history, the results of physical examination, and laboratory data were recorded for each patient on admission on a standard form. Further results of examinations and laboratory tests were subsequently recorded every 48 hours. Blood tests were performed for the first 230 patients within 48 hours after admission.

The table shows the clinical symptoms, physical findings, and results of laboratory tests. Serum aspartate transaminase and lactic dehydrogenase activities were found to be abnormally high in $155(67 \%)$ and $163(71 \%)$ of the patients respectively. These figures increased to $173(75 \%)$ and $198(86 \%)$ respectively
1 Krugman S. Present status of measles and rubella immunization in the United States: a medical progress report. F Pediatr 1977;90:1-12.

Israel Ministry of Health. Measles in Israel. Monthly Epidemiol Bulletin 1981;16:11-5.

3 Rand KH, Emmons RW, Merigan TC. Measles in adults: an unforeseen consequence of immunization? FAMA 1976;236:1028-31.

4 Gavish D, Kleinman Y, Morag A, Chajek-Shoul T. Hepatitis and jaundice associated with measles in young adults. An analysis of 65 cases. Arch Intern Med 1983;143:674-7.

5 Christie AB. Measles. In: Christie AB, ed. Infectious diseases: epidemiology and clinical practice. Edinburgh: Churchill Livingstone, 1980:357-86.

(Accepted 25 August 1987)

Department of Medicine T, Ichilov Hospital, Tel-Aviv Medical Centre, Tel-Aviv 64239, Israel

MICHAEL GILADI, MD, MSC, resident in internal medicine

Medical Corps, Israel Defence Forces, PO Box 02149, Israel

ADRIAN SCHULMAN, MD, research fellow

RON KEDEM, BSC, chief statistician

YEHUDA L DANON, MD, surgeon general

Correspondence to: Dr Giladi. 